\title{
The Results of Y-DNA and Mitochondrial Haplogroup Testing of an Ancient Burial of XII-XIV Centuries in Old Vladimir Patriarch's Garden Site Near the Klyazma River
}

\author{
Sergey Z. Chernov ${ }^{1}$, Larisa L. Chernyaeva ${ }^{2}$, Natalia N. Goncharova ${ }^{3}$, Danil A. \\ Kabaev $^{2}$, Svetlana V. Ocheretina ${ }^{2}$, Alexander S. Semenov ${ }^{4, *}$ \\ ${ }^{1}$ Moscow Rus Archaeology Department, Institute of Archaeology of the Russian Academy of Sciences, Moscow, Russia \\ ${ }^{2}$ LLC "Vladimir Region Center for Archaelogy of the Vladimir State University", Vladimir, Russia \\ ${ }^{3}$ Faculty of Biology, Moscow State University, Moscow, Russia \\ ${ }^{4}$ Moscow Institute of Physics and Technology, Dolgoprudny, Russia \\ ${ }^{*}$ Corresponding author. E-mail: semyonov1980@mail.ru
}

\begin{abstract} haplogroup with high probability.

\section{INTRODUCTION}

The paleoDNA testing becomes one of the new challenging and resultative branches of modern biotechnology. Modern technology allows high-quality DNA extracting and analysing it by various number of methods including Ychromosome and mitochondrial DNA haplogroup defining. It can give a valuable insight to define the affinity of an ancient population to other ancient and modern population groups including living people.

The main aim of the research was to make a haplogroup testing for a Russian medieval burial and to look at its possible analogs in other medieval DNA samples. For the test object a skull excavated in 2017 from the medieval Vladimir cemetery dating back to the 13th-14th centuries was chosen. The first reason for that choice was a serious significance of the Vladimir region in the processes of the Slavic settlement of North-Eastern Russia and the second reason was the good quality of preservation of the skull and the $100 \%$ gender determination. The excavations were executed by LLC «Vladimir Region Center for Archaelogy» and the leaders of the excavations were Dr. S.V. Ocheretina and Dr. D.A. Kabaev.
\end{abstract}

The work describes the results of the experiment on Y-DNA and mitochondrial haplogroup defining of an ancient burial in Vladimir Area. The obtained data help to define the Y-haplogroup and mitochondrial haplogroup according to genetic markers studied in the research. The paper outlines the experiment, technology, and the obtained result which defines R1a-M458-L1029 Y-haplogroup and H6c1 mitochondrial

Keywords: gene pool, population genetics, paleo-DNA, contamination, SNP and STR markers of Ychromosome, mt-DNA, haplogroups, sequencing, identity, medieval genome

The excavations were made from the burial ground on the territory of the Patriarch's Garden in 2016-2017. The burial ground (old cemetery) is located on high promontory formed by the southern slope of the left bank of the river Klyazma and the slope of the relief depression on which the garden is located. There were investigated about 180 burials on an area of more than $1000 \mathrm{~m}^{2}$. For the experiment described, the Burial 7 from Excavation 2 was taken. Currently, the materials of the repository are being processed and studied, and the research results of whole cemetery will be presented later.

The experiment of Y-haplogroup and mitochondrial haplogroup testing of the described ancient burial was undertaken in March-July 2020 by the agreement with LLC «DNA-Nasledie» and all the analysis procedure was performed by LLC «DNA-Nasledie». The ancient sample was taken from the collection in Vladimir. The burial contained fragments of skull and teeth. The date of the sample is the end of XIII - beginning of XIV century and the burial mode was of Christian type.

For testing, two sample teeth from the burial were chosen by the research group. These teeth were transferred in 2020 to the office of LLC «DNA-Nasledie». The reseach was carried out according to the commercial agreement №DNALA/01-20 dated by 10 January 2020 with LLC «DNANasledie». 


\section{METHODOLOGY}

DNA analysis was carried out in a module, consisting of four glove boxes. To avoid contamination, each box was strictly separated from others and from the environment, and atmosphere air was replaced by neutral gas of high purity.

The DNA from the teeth was extracted by means of the method with $\mathrm{SiO}_{2}$ columns, what is used in criminalistics and forensic medicine for the extraction of degraded DNA from complicated objects. The method is described in [1]. Obtained DNA was analyzed by means of the standard molecular genetic techniques, including real-time PCR on AB7500 equipment. Measurement of the concentration of the isolated DNA was carried out on a Qubitv2 fluorimeter on High Sensitivity chemistry.

For the research two independent DNA extractions were made. For Y-DNA analysis the concentration was $15 \mathrm{ng}$ in $\mu \mathrm{l}$, from powder of 6 gramm. For mitochondrial DNA analysis the concentration of isolated DNA was $7 \mathrm{ng}$ in $\mu \mathrm{l}$ from powder of 2 gramm. The fragment analysis for $\mathrm{Y}$ DNA was carried out on the same AB 3500xl analyzer. STRs were scanned at loci, the commercial Yfiler TM Plus kit (TermoFisher) was used with 27 STR markers.

Analysis of mitochondrial DNA was carried out using NGS sequencing. Target sequencing (NGS) of hypervariable regions (I-III) of the mtDNA was performed using

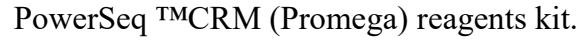

\subsection{Experimental Design and Procedure}

All stages of work with the archaeological sample were carried out in glove boxes, in which the atmospheric air was replaced by a neutral gas of high purity. The procedure included the following stages:

1. Sterilization of all instruments and working space in the boxes with the help of chemicals and hard UV-irradiation within 24 hours.

Table 1 Obtained Data and Comparison with Russian Analog

\begin{tabular}{|c|c|c|}
\hline Name and alleles of STR loci & $\begin{array}{c}\text { Vladimir, Patriarch's Garden, } \\
\text { ex.2, №7, XIII-XIV cent. }\end{array}$ & $\begin{array}{c}\text { Radonezh, Burial №1 } \\
\text { (Kv-A-B/1-2) XVI-XVII cent. }\end{array}$ \\
\hline 393 & 13 & 13 \\
\hline 390 & 25 & 14 \\
\hline 19 & 15 & 11 \\
\hline 391 & 10 & 14 \\
\hline $385 \mathrm{a}$ & 11 & 13 \\
\hline $385 \mathrm{~b}$ & 14 & 11 \\
\hline 439 & 11 & 13 \\
\hline $389 \mathrm{I}$ & 13 & 11 \\
\hline 392 & 11 & 13 \\
\hline
\end{tabular}

2. The primary mechanical cleaning of the ancient tooth from the surfacelayer of impurities on specialized equipment with dental milling cutters and secondary cavitation cleaning with ultrasound.

3. Grinding of the purified bones in a ball mill. As a result, a bone powder was obtained.

4. DNA extraction from the bone material was carried out by the method based on silicone columns.

5. The concentration contained DNA fragments from 20 to $180 \mathrm{bp}$ in length. During the PCR reaction, STR fragments of the $\mathrm{Y}$ chromosome from 90 to $180 \mathrm{bp}$ in length were successfully amplified. Fragments of greater length did not survive due to DNA degradation.

6. As a result of electrophoresis of PCR products on the fragment sequencer AB3500xl and analysis of foreograms, 27 STR loci of the Y chromosome with the values of the alleles indicated in Table 1 were reliably detected (Phoreogramme in Figure. 1 depicts numerically only part of the values). Detection results «out of machine» in initial representation are given in Figure. 2.

7. Analysis of mitochondrial DNA was carried out using a NGS sequencing method with PowerSeq ${ }^{\text {TMCRM }}$ (Promega) reagents kit and the results are shown below.

\subsection{Data and interpretations}

The experiment resulted in following data for $\mathrm{Y}$ chromosomal haplogroup (YFiler mode). The Y-DNA analysis showed the R1a-M458 Y-DNA haplogroup, typical for the Slavic and other Central European populations. The result can be grouped with other still scarce Slavic Y-DNA medieval data from Russia and with results from Western Slavic regions. 


\begin{tabular}{|c|c|c|}
\hline 389 II & 29 & 29 \\
\hline 458 & 17 & 16 \\
\hline 437 & 14 & \\
\hline 448 & 20 & 20 \\
\hline 449 & 32 & 32 \\
\hline 460 & 11 & 11 \\
\hline GATAH4 & 12 & 10 \\
\hline 456 & 16 & 17 \\
\hline 576 & 18 & 16 \\
\hline 570 & 18 & \\
\hline 438 & 11 & 11 \\
\hline 481 & 23 & 25 \\
\hline 533 & 12 & \\
\hline 635 & 23 & 23 \\
\hline 627 & 16 & 22 \\
\hline 518 & 42 & \\
\hline F387S1 a & 35 & 32 \\
\hline F387S1 b & 38 & 37 \\
\hline
\end{tabular}

As the number of data is still small, in this paper we compare the result with a direct DNA analogy of a burial from Radonezh archaeological site [2, 3] in Moscow Region near border with Vladimir Region. At the medieval layers of the Radonezh burial ground, excavations in 19881990 uncovered 38 burials, as well as remnants of 107 destroyed burials (according to the number of skulls). The excavations were headed by professor V.I. Vishnevsky. Fragments of white stone tombstones from the graves date back to the first half and middle of the 16th century were found. In burial 13, in the right hand of a skeleton, a silver coin from 1560-1584 was found.

In Radonezh DNA research Burial №1 (Kv-A-B/1-2) was studied. «Burial №1 (Kv-A-B/1-2). No traces of a pit. The burial is filled by light-brown soil with ceramic fragments. It is oriented to the South-West by the head, azimuth 245 degrees. The depth is 0.9 from the surface. The bones are of medium safety, the skeleton lies on the right side. The knees lie $20 \mathrm{~cm}$ from each other. The feet and shins were destroyed by later burials. The hands are folded together. The orbits are oriented towards the South-West. The skeleton is attributed to a man of the age about 25 years. In the nose bridge and in the crown area there are small oval holes of around $1 \mathrm{~cm}$ diameter. An iron knife was found near the hips, a bronze cross with the Calvary depiction was found below the right shoulder. The cross was dated by M. V. Sedova by 16th-17th centuries. During the excavating, just below the burial, another burial was found (burial №13) $[2,3]$.

Burial №1 is an exception in the position of the backbone and the placement of arms. It can be explained either by a casually neglected coffin, in the event that the funeral took place in an extreme situation. The deceased died a violent death as just above the bridge of the nose, bullet holes were found towards the top. Probably, the haste of the funeral is explained by the presence of artefacts with the deceased: a cross on the chest and a knife in a leather sheath on the belt (while all the burials, except for two, are non-inventory). The small depth of the grave is explained by the fact that the gravediggers at the hood came across the skeleton of an earlier burial, and rather than pull it out, they put the deceased on top. Burial №1 was taken out by a monolith and brought to the museum, and while dismantling it directly under burial skeleton 1, one earlier skull (skull №2) was found» $[2,3]$.

This burial can be mentioned as the direct DNA-analog of the described newly introduced one from Vladimir Patriarch's Garden cemetery.

The definition of Y-haplogroup with 27 loci according to the computer predictor NEVGEN [4] based on actual Yhaplotype data (database of the predictor is dated by 30.08.2020) gives $99 \%$ probability of R1a Y-haplogroup, and the most probable subclade is R1a-M458-L1029 (the obtained phoreogramme is given in figure 1). The 
haplogroup of Radonezh burial was detected the same with 97\% probability of R1a and most probable subclade is the same R1a-M458-L1029. We see the coincidence of many loci values in both samples analysed.

Analysis of NGS sequencing for mitochondrial haplogroup gives the following values of HVRI and HVRII in mitochondiral haplogroup sequence of studied sample.

HVRI: $16400 \mathrm{~T}, 16482 \mathrm{G}$

HVRII: 239T, 263G, 315.1C.

According to FTDNA haplogroup defining mutation list [5], it can be interpreted and assigned as H6cl subclade by mutations $239 \mathrm{~T}$ and $16400 \mathrm{~T}$ occurring simultaneously. The both mutations identify the subclade in unique way. No ambiquity is possible in this case as it happens sometimes in other cases for several different HVRI and HVRII combinations. 


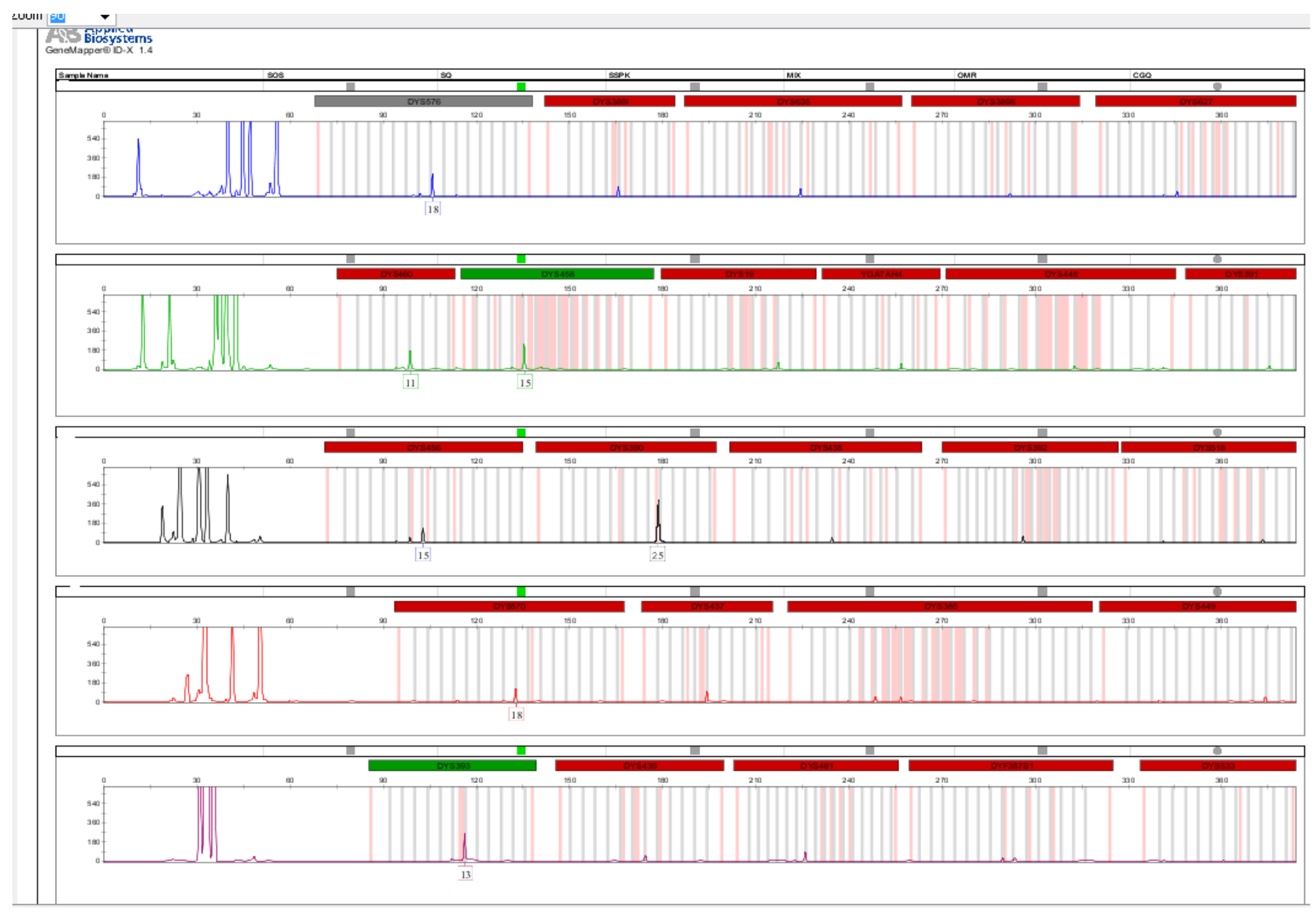

Figure 1 Phoreogramme of Y-haplotype STR loci of the studied sample 


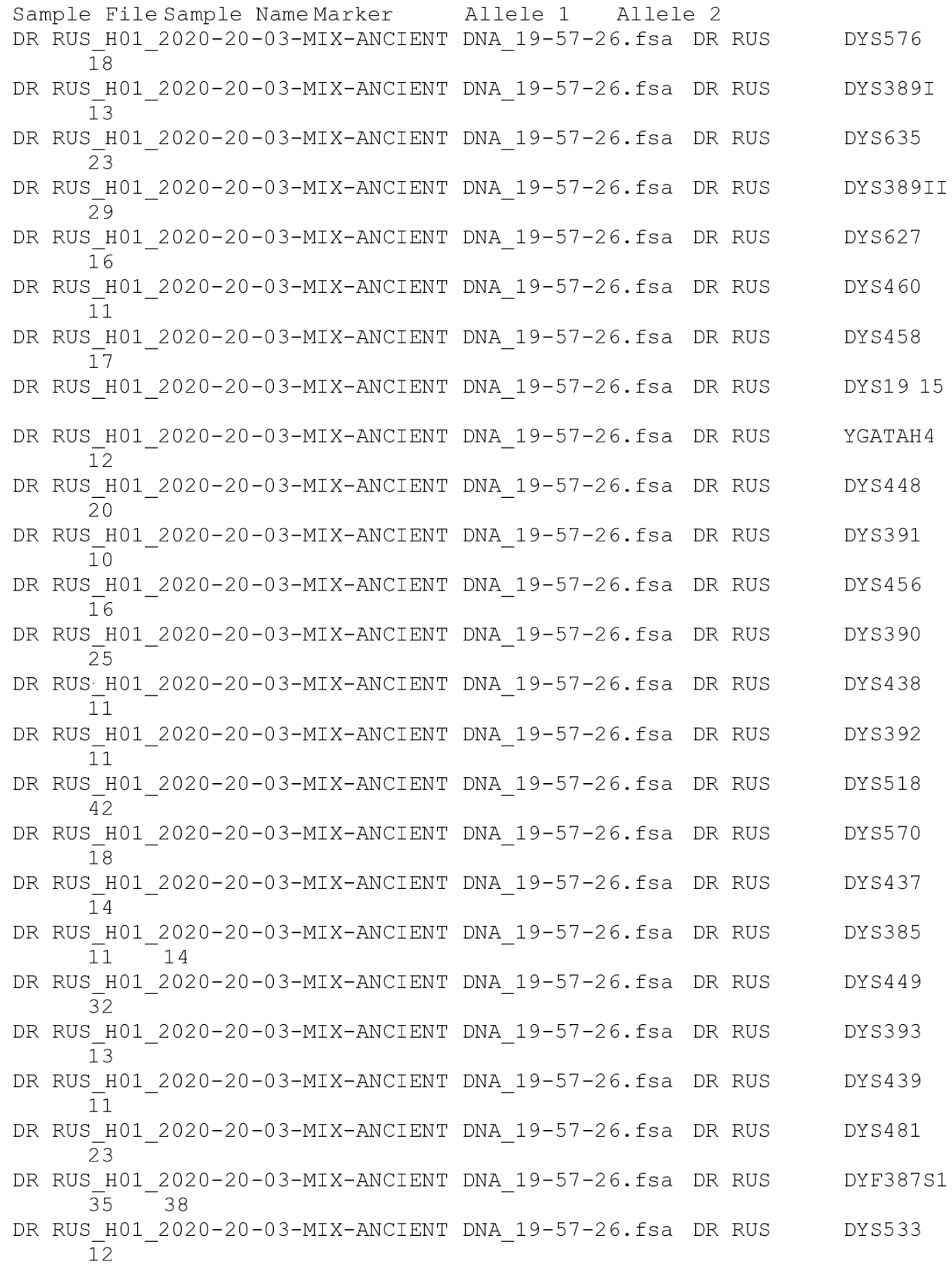

Figure 2 Result of detection of Y-haplotype STR loci in initial form «out of machine»

\section{DISCUSSION AND ANALYSIS}

Subclade R1a-M458 is considered as a subhaplogroup inherent to Slavic and Baltic people, with maximal density in Poland, Lithuania, Czech Republic, Slovakia, Ukraine, and North-Western Russia [3]. The main area is limited to Poland, the Czech Republic, and Slovakia. In central and southern Poland, the frequency of haplogroup reaches its 
maximum, about $40 \%$, while in the north, east, and southwest the range is from 15 to $23 \%$. In the Czech Republic it is $25 \%$, and $18-25 \%$ in Slovakia. Subclade M458 is present more to the East as well. In the eastern part of Europe, the frequency of M458 is still high, for example, in Ukraine and Belarus from $7 \%$ to $22 \%$ in the eastern part of Ukraine and Western Russia. Maximum frequencies in Russia are recorded in the Orel region (14\%), and in the Pskov, Belgorod and Kostroma regions (uniformly up to 12 $\%)$. Further to the east, in the Tatar populations, the measure is approximately $4-5 \%$. In the west of Poland and in Germany, the R1a-M458 frequency drops slightly to 10 $\%$. In the Balkans it is also present: $9 \%$ in Croatia, $8 \%$ in Bosnia, $5 \%$ in Albania, $5 \%$ in Romania, $4 \%$ in Greece, 4 $\%$ in Macedonia, $3 \%$ in Serbia, and $2 \%$ in Slovenia. In Scandinavia, the frequency of haplogroups is greatly reduced to $2 \%$ in Swedes, although in Denmark it is about $4 \%$.

The old DNA from East Slavic people is still known and published by a limited amount of data. We know two DNA sets from Western Slavic people. In two works from Germany, a group of results has already been obtained from a burial in Usedom, on the Polish-German border, and in Saxony-Anhalt, near Dresden (burial of Krakauer Berg), which indicate the presence of the West Slavic subclade R1a-M458.

Mitochondrial haplogroup $\mathrm{H}$ is the most common mitochondrial haplogroup in Europe, as it includes more than half of the modern female population of North-West Europe. This haplogroup is also common in North Africa and the Middle East. The frequency of the spread of this haplogroup in Europe decreases towards the southeast part of the Eurasia, accounting for only $20 \%$ in the Middle East and the Caucasus, and less than $10 \%$ in the Persian Gulf, North India, and Central Asia. As it is shown further the subclade H6c is inherent to Central and Eastern Europe Concerning Vladimir area population process, the determination in a burial at the end of the 13th - beginning of the 14th century in the Patriarch's Garden of Vladimir, of haplogroup Y-DNA R1a-M458 in combination with mtDNA H6c1 does not contradict the assumption that the ancestors of buried man belonged to the Slavic population that settled in North-Eastern Russia. At the same time, the probability of movement direction from the Western part of Slavic world is not excluded (for example, the process of movement of Slavic people to XII century Klyazma River settlements from the western side was described in [6]).

Two medieval R1a-M458 from Usedom (12th-14th centuries, German-Polish border) [7] and Krakauer Berg (11th-15th centuries) [8] support this view. One R1a-M458 was fixed even westwards in Netherlandish burial Oldenzaal (14th century) [9].

Mitochondrial haplogroup H6, having counterparts in modern Poland, also fits this view. According to [10] haplogroup H6 is very interesting because two its branches, H6a and H6b, are characteristic, correspondingly, for European and Central Asian/Near Eastern populations, thus reflecting a long-time separation of Asian and European H6
mtDNA pools. Mitochondrial haplogroup H6c has its representatives in Central an Eastern Europe, especially in Poland.

The research revealed that the medieval Russian people from the Vladimir and Radonezh of XIII-XVI centuries had the typical subclades of Northern and Eastern Europe and Slavic original is the most probable.

\section{CONCLUSION}

The first evidence of the presence of R1a-M458 among the population of North-Eastern Russia in the XIII-XVI centuries. (Radonezh, Vladimir) not only supports the view of R1a Y-haplogroup presence for all medieval Russian lands, regardless of princedom borders, but also hints that certain genetic unity with the western parts of Slavic areal could exist (as the most serious concentrations of R1aM458 are noticed in the western part of the Slavic areal). We conclude that the experiment was proper and a positive result is obtained. In conclusion, the experiment of haplogroup estimating on a new and recently introduced burial showed that the method developed at the Moscow Institute of Physics and Technology works well for the medieval samples in Russian soil and can be a good base for future development of historical genetics of Russia.

\section{REFERENCES}

[1] A.D. Matsvay, I.E. Alborova, E.V. Pimkina, M.L. Markelov, K.F. Khafizov, Kh.Kh. Mustafin, Experimental approaches for ancient DNA extraction and sample preparation for next generation sequencing in ultra-clean conditions, Conservation Genetics Resources 11 (2019) 345-353.

[2] Kh.Kh. Mustafin, I.E. Alborova, V.I. Vishnevsky, A.S. Semenov, Haplogroup analysis for a Medieval Russian burial of 16th-17th centures in Radonezh (Moscow Area), Studia Slavica et Balcanica Petropolitana 2 (2018) 169-180.

[3] Kh.Kh.Mustafin, I.E. Alborova, V.I.Vishnevsky, A.S. Semenov, The first results of Y-DNA haplogroup testing for a medieval Russian burial of the 16-17 centuries in Radonezh (Moscow area), Rusin 1(47) (2017) 106-110.

[4] Y-haplogroup predictor NEVGEN, Available at: www.nevgen.org.

[5] FTDNA haplogroup defining mutation list, Available at: https://www.familytreedna.com/mtDNAHaplogroup-Mutations.aspx. 
[6] S.Z. Chernov, N.N.Goncharova, V.I.Merkulov, A.S. Semenov, Test results of Y-DNA haplogroup for the medieval slavic burial of the 12th century near Zagoryansky settlement on the Upper Klyazma (Moscow Region), Rusin 58 (2019) 13-25.

[7] J. Freder, Die mittelalterlichen Skelette von Usedom: Dissertation Free, Berlin, University of Berlin, 2010, 206 p.

[8] C. Parker, A.B. Rohrlach, S. Friederich, S. Nagel, M. Meyer, J. Krause, K.I. Bos, W. Haak, A systematic investigation of human DNA preservation in medieval skeletons, bioRxiv.org, Available at: https://www.biorxiv.org/content/10.1101/2020.05.20.106 971v1.

[9] P. Reusink, Determination of biological relationships within the medieval and post-medieval cemetery of the St. Plechelmus church in Oldenzaal using ancient DNA, Master thesis Human Osteology and Funerary Archaeology at the Faculty of Archaeology, Leiden University, 2014.

[10] M. Mielnik-Sikorska, P. Daca, B. Malyarchuk, M. Derenko, K. Skonieczna, M. Perkova, T.Dobosz, T. Grzybowski, The history of Slavs inferred from complete mitochondrial genome sequences, PLoS One 8(1) (2013) e54360. DOI:

10.1371/journal.pone.0054360. Epub 2013 Jan 14 